\title{
A WAY TO UNITE GEOLOGY AND GEOTECHNICAL ENGINEERING THROUGH THE RECENT UNDERSTANDING OF SOIL BEHAVIOUR AND DEVELOPMENT IN MATHEMATICAL MODELS
}

\author{
Charles $\mathrm{Ng}^{1)}$ and Yoshinori Iwasaski ${ }^{2}$ \\ 1) Department of Civil and Structural Engineering, Hong Kong University of Science and \\ Technology, Clear Water Bay, Hong Kong \\ 2) Geo Research Institute, Itachibori, Nishi - ku, Osaka, 550, Japan
}

(Received: 24 November 1995; Accepted: 31 January 1996)

\begin{abstract}
Nearly all engineering structures are supported in some way on natural earth ma terials; this inevitably creates an interaction between geological conditions and foundation analysis, design and construction. Thus, both geologists and geotechnical engineers have a vital role to play in many engineering operations which interact with the ground. In this pa per, the interplay between geotechnical engineers and geologists is discussed.

To analyse and design geotechnical engineering works in urban areas, the practice of geotechnical engineers includes the study of the mechanical properties of natural earth mate rials and, very often, the use of mathematical models to describe the fundamental behaviour of these materials. With the help of recent advances in techniques of site investigation and laboratory testing, new insights into soil stress - strain relationships at small strains and re cent stress history effects have been gained and are introduced in this paper. In addition, some mathematical soil models such as the non-linear Brick model, which has the capability to capture these new observed soil behaviour, is discussed and examined. The use of geologi cal information in assisting the back - analysis of a case history in the city centre of Cam bridge is illustrated. The ongoing processes of field monitoring and back-analysis can help to refine and improve our understanding of the behaviour of soil structure interactions, which in turn provides guidance for future design. It is intended that through the introduction, dis cussion and illustration, geologists will have a better understanding of soil behaviour. It is hoped that this understanding will help to create a better partnership between geologists and geotechnical engineers in the future.
\end{abstract}

Key Words : Stress - strain relationship, small strains, recent stress history, Brick model

\begin{tabular}{ll} 
& \multicolumn{1}{c}{ NOTATION } \\
$\mathrm{c}_{\mathrm{u}}$ & undrained shear strength \\
$\mathrm{E}_{\mathrm{u}}$ & undrained Young's modulus \\
$\mathrm{f}, \mathrm{F}$ & two non - linear functions \\
$\mathrm{G}$ & shear modulus $\left(1 / 3 \mathrm{dq} / \mathrm{d} \varepsilon_{\mathrm{s}}\right)$ \\
$\mathrm{G}_{\mathrm{t}}$ & tangent shear modulus \\
$\mathrm{N}$ & standard penetration "N" value \\
$\mathrm{K}^{\prime}$ & effective bulk modulus $\left(\mathrm{dp} \mathrm{p}^{\prime} / \mathrm{d} \varepsilon_{\mathrm{v}}\right)$ \\
$\mathrm{K}_{\mathrm{o}}$ & coefficient of earth pressure at rest \\
$\mathrm{K}_{\mathrm{onc}}$ & coefficient of earth pressure at rest for nor - \\
& mally consolidated soil \\
$\mathrm{K}_{\mathrm{p}}$ & passive earth pressure coefficient \\
$\mathrm{LDT}$ & linear displacement transducer \\
$\mathrm{OCR}$ & overconsolidation ratio \\
$\mathrm{p}^{\prime}$ & $\left(\sigma_{1}^{\prime}+2 \sigma_{3}^{\prime}\right) / 3$ \\
$\mathrm{q}$ & $\sigma_{1}^{\prime}-\sigma_{3}^{\prime}$ \\
$\mathrm{s}^{\prime}$ & $\left(\sigma_{1}^{\prime}+\sigma_{3}^{\prime}\right) / 2$ \\
So & mean normal stress in a slurry state \\
$\mathrm{SBPM}$ & self - boring pressure meter \\
$\mathrm{t}$ & $\left(\sigma_{1}-\sigma_{3}\right) / 2$ or $\left(\sigma_{1}^{\prime}-\sigma_{3}^{\prime}\right) / 2$ \\
$\mathrm{v}$ & volumetric strain $\left(\varepsilon_{1}+\varepsilon_{3}\right)$ \\
$\mathrm{vo}$ & volumetric strain in a slurry state \\
$\beta$ & material constant allowing for overconsoli - \\
$\gamma$ & dation effects \\
$\gamma$ & shear strain $\left(\varepsilon_{1}-\varepsilon_{3}\right)$
\end{tabular}

$\delta \quad$ small increment

$\Delta \quad$ increment

$\delta \mathrm{s}^{\prime} \quad$ incremental mean effective normal stress

$\delta \mathrm{t} \quad$ incremental shear stress

$\delta \mathrm{vc}_{\mathrm{c}} \quad$ additional elastic volumetric strain capacity

$\delta$ ve incremental elastic volumetric strain

$\delta \gamma_{\mathrm{c}} \quad$ additional elastic shear strain capacity

$\delta \gamma_{\mathrm{e}} \quad$ incremental elastic shear strain

$\varepsilon_{\mathrm{L}} \quad$ axial strain

$\varepsilon_{\mathbf{x}}, \varepsilon_{\mathbf{y}} \quad$ normal strains

$\varepsilon_{\mathrm{s}} \quad$ shear strain $\left(2\left(\varepsilon_{1}-\varepsilon_{3}\right) / 3\right)$

$\varepsilon_{\mathrm{v}} \quad$ volumetric strain $\left(\varepsilon_{1}+2 \varepsilon_{3}\right)$

$\varepsilon_{1}, \varepsilon_{3} \quad$ principal strains

$\iota$ initial slope of unload/load line in $\mathrm{v}-\operatorname{lns}{ }^{\prime}$ space

$\kappa \quad$ average slope of unload/load line in $\mathrm{v}-\ln \mathbf{s}^{\prime}$ space

$\lambda \quad$ slope of $1 \mathrm{D}$ compression line in $\mathrm{v}-\ln \mathrm{s}^{\prime}$ space

$\mu^{\prime} \quad$ effective Poisson's ratio

$\sigma_{h}^{\prime} \quad$ horizontal effective stress

$\sigma^{\prime} \quad$ vertical effective stress

$\sigma^{\prime}{ }_{1}, \sigma^{\prime}{ }_{3}$ principal effective normal stresses

$\phi^{\prime} \quad$ effective angle of friction 


\section{INTRODUCTION}

This paper discusses the relationship between en gineering geologists and geotechnical engineers with emphasis on the importance on collaboration. To improve understanding between the two, the paper in troduces the current knowledge of the stress - strain behaviour of soils at small strains and a state-of -the - art soil model, which has the ability to mimic the soil behaviour. This model is subsequently used to back-analyse an urban deep excavation for which the knowledge of both geology at the excavation and the soil behaviour at small strains is vital to understand the soil - structure interaction of the excavation.

\section{INTERPLAY BETWEEN ENGINEER - ING GEOLOGISTS AND GEOTECH - NICAL ENGINEERS}

Nearly all engineering structures are supported in some way on natural earth materials, which in evitably creates a connection between geological conditions and foundation analysis, design and construc tion. To assist with the analysis and design of these engineering structures, geotechnical engineers study the physical and mechanical properties of natural earth materials and very often use mathematical models to describe the fundamental behaviour of these materials. On the other hand, geologists nor mally study the composition and arrangement of the earth's crust from which all these natural earth materials are derived.

There is a widespread recognition of the vital im portance of geology to those who practise the art of geotechnical engineering. Under the name of soil mechanics, geology is also commonly included as a basic subject in the training courses for geotechnical engineers. Geological considerations are essential for the design of many civil engineering structures.

When geologists are called in to advise in geotechnical engineering work, they will act in conjunction with the engineers responsible for the work. Thus, the need for co-operation arises between geotechnical engineers and engineering geologists. Their co-operation may lead to a valuable partner ship. In some ways, their partnership is a union of opposites, for the approach of the two to the same problem is psychologically different. The geologists analyse natural conditions as they are; the engineers consider how the existing natural conditions can be altered so that they will suit a specific safe, economi cal and environmentally friendly engineering design. The geologists draw on their analysis to cite problems that exist naturally and suggest problems that may arise; the engineers must solve the problems and overcome the difficulties. The final responsibility for decisions concerning the project must always rest with the engineers; but in reaching such decisions, the engineers will be guided by and will probably rely upon the factual information provided by the geologists.

It is important to steadily develop liaison and un - derstanding between the scientific approach to the geology of rocks and soils and the engineering inves tigation of their properties to assist in building up this valuable partnership between engineering geologists and geotechnical engineers. It is inevitable that this interaction will progress to the mutual benefit of both geology and geotechnical engineering and to the continued advance of human understanding of the most common of all solid materials.

To ensure the valuable partnership, the joint work calls for a great degree of real co-operation. The engineering geologists must remember that what the engineers want is a clear picture, presented as concisely as possible, of the geological conditions re lated to the work, with a view to practical utilization. On the other hand, the engineers must remember that the geologists are not engineers, and they cannot be expected to deliver the kind of report that would come from other engineers. Under many circumstances, the most effective results can be achieved if the engineers are able to give the geologists at the outset a list of specific questions to be answered. The questions may relate to geological conditions, and to the neces sity for and the locations of further exploratory works such as boreholes and exploratory pits.

\section{SOIL MECHANICS AND GEOLOGY}

Soil mechanics is the universally accepted geotechnical term for the engineering study of soils. However, what is soil and what is rock remains a de batable subject in many cases. Soil mechanics owes its origin to Karl Terzaghi, an Austrian civil engi neer, who is generally recognised as the father of soil mechanics. His famous book on soil mechanics pub lished in 1925, Erdbaumechanik auf bodenphysikalis cher Grundlage, translated by A. Casagrande into the English From theory to practice in soil mechan$i c s$, is now credited as being the birth of soil mechan ics. Since then, soil mechanics and geotechnical en gineering have rapidly evolved in response to im mense construction projects such as airfields in the 1940s, the vast network of highways and bridges built in the 1950s and 1960s, and the large amount of land reclamation, deep excavations and tunnels construct ed in recent years.

"Unconsolidated materiäls" (geologists) and "soils" (geotechnical engineers) describe those natu ral materials found in the earth's crust that consti tute so large a part of the actual surface of the earth that few geotechnical engineering operations apart from rock tunnelling can be constructed without an encounter with soil of some type. Since it will not al ways be economical to make foundations in solid rock, the founding of structures on "unconsolidated materials" or "soils" is probably the most important part of geotechnical engineering. Geologists and soil mechanicians generally maintain different levels of appreciation of soils. The geologists normally have an ingrained interest in origin, and the soil mechani cians are preoccupied with soil types and their par 
ticular mechanical properties.

Unlike most other engineering materials, soils originate from various geological processes such as deposition, erosion and weathering. Many engineered works come in close proximity to soils. Prob lems and difficulties in design and construction are many times more frequent when structures are to be founded on soil rather than on bedrock. Over recent years, increasing emphasis is being placed on geolog ical engineering and mechanical evaluation of soils. When soil and rock mechanics have become vital parts of the scientific core of geotechnical engineer ing, the scientific study of rocks and soils must have contact with geology. Soil mechanics closely approaches a geological study when field investigations are involved. It would be virtually impossible to con duct field studies of soil without reference to the local geology. However, some soil studies have been conducted in the field without benefit from contact with geology in any form. Sometimes no harm has result ed, but this has been through good luck rather than through an appropriate management system. Poor results have of ten been obtained through patent neglect of geological features. In many cases, money has been spent unnecessarily because subsurface ex plorations were not co-ordinated with local geology, and occasionally the neglect of geology has had disas trous results. It can therefore be stated that studies of soil mechanics in the field are incomplete without some consideration of the appropriate local geology. Herein lies perhaps the chief contact between geology and soil mechanics.

\section{OBSERVED NON-LINEAR STRESS - STRAIN BEHAVIOUR OF SOILS AT SMALL STRAINS}

\section{Non-linear stress-strain relationship}

Weathering and surficial geological processes produce weathered rocks and surficial deposits, called "soil". An important aspect of geotechnical engineering is the understanding of the mechanical behaviour of soils, from which engineering calcula tions and mathematical models for soil behaviour are formulated.

The assumption of a linear stress-strain rela tionship of soil inside the state boundary surface (Schofield and Wroth, 1968) has been applied to almost all geotechnical engineering practice for years. Only recently has it been widely accepted that the stress - strain relationship is highly non-linear even at very small strains (see Figure 1), a fact that emerged from recent advances in both laboratory (Atkinson and Sallfors, 1991; Goto et al. 1991) and field measur ing techniques (Tatsuoka and Kohata, 1994). Typical strain ranges for retaining walls, foundations and tunnels constructed in stiff soils such as stiff clays and dense sands are over the range of strains where there is the greatest variation of stiffness. The stiff ness of most soils decreases as strain increases and the stiffness at small strains is strongly dependent on the current state and the recent stress or strain histo ry of each soil element (Atkinson et al., 1990).

Conventionally, the determination of the axial soil stiffness of a triaxial sample is based on external measurements of displacement which include a num ber of extraneous movements. The true soil strains developed can be easily masked by these movements, leading to a poor definition of stress-strain be haviour of the material under test, particularly over a small strain range. The important sources of error (Jardine et al., 1984) are illustrated in Figure 2. Some of the deflections shown in the figure may be quantified by careful calibration, but large unaccountable errors remain due to:

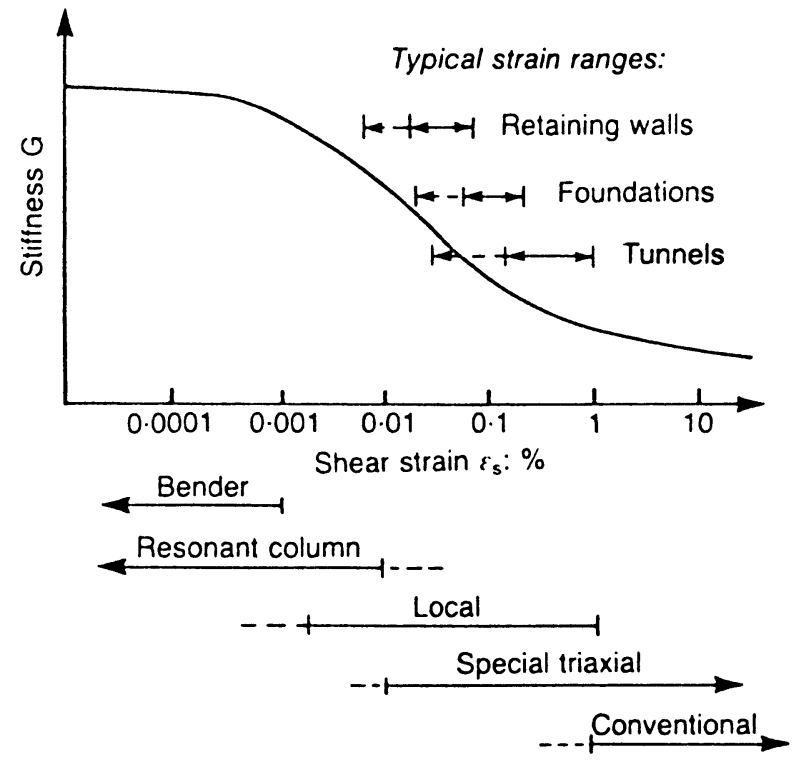

Fig.1 Approximate strain limits for soil structures (Mair, 1993)

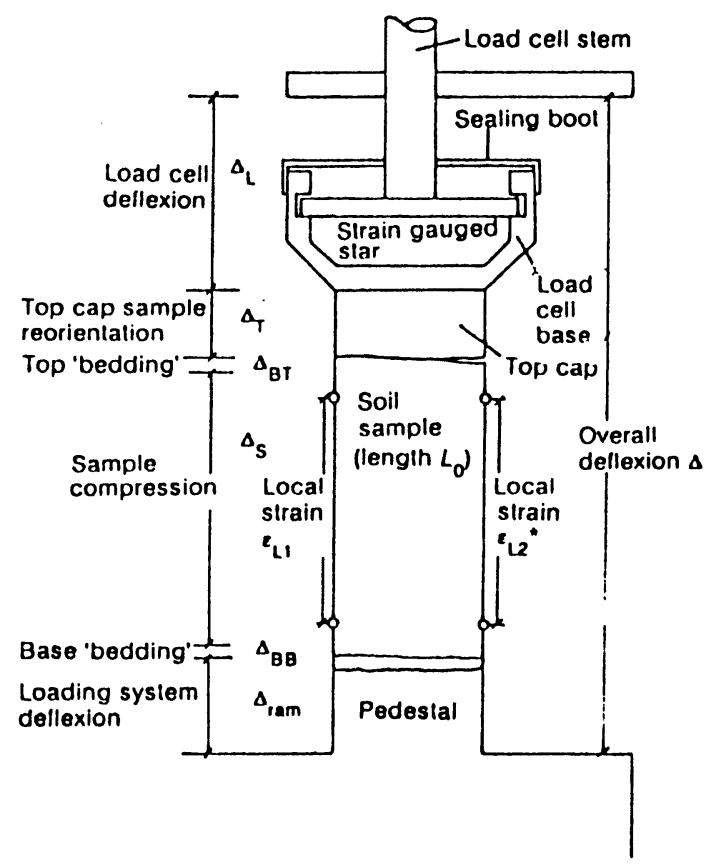

Fig.2 Sources of error in external strain measure ments (Jardine et al., 1984) 
(a) The difficulty of trimming a sample so that the end faces are perpendicular to the vertical axis of symmetry.

(b) Play in the connection between the load cell and the sample top cap.

(c) The inevitable "bedding down" at the ends of the sample, due to local surface irregulaities or voids.

Therefore, most triaxial tests tend to give appar ent soil stiffnesses far lower than those inferred from field observations.

The revolution of static and dynamic stiffness measuring devices (Tatsuoka and Kohata, 1994; Jar dine, 1994) enabled accurate measurement of soil stiffness at small strains on soil samples subjected to different stress histories and stress paths. Figure 3 shows the small strain measuring device - LDT for use in a triaxial test. Local deformation is measured by two thin strain gauged strips of phosphor bronze directly attached to the sample on which two hinges are mounted. As the soil deforms, the distance be -

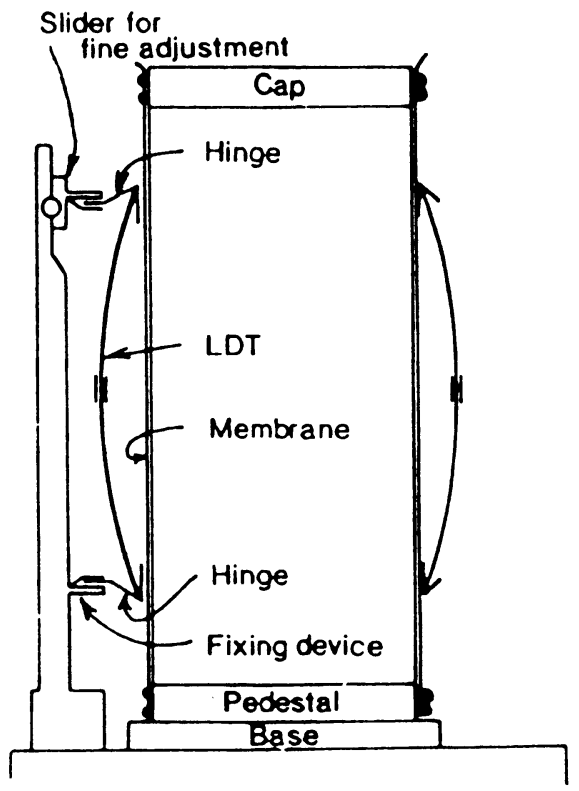

Fig.3 Local measurement of axial strain using a pair of LDTs (Goto et al., 1991)

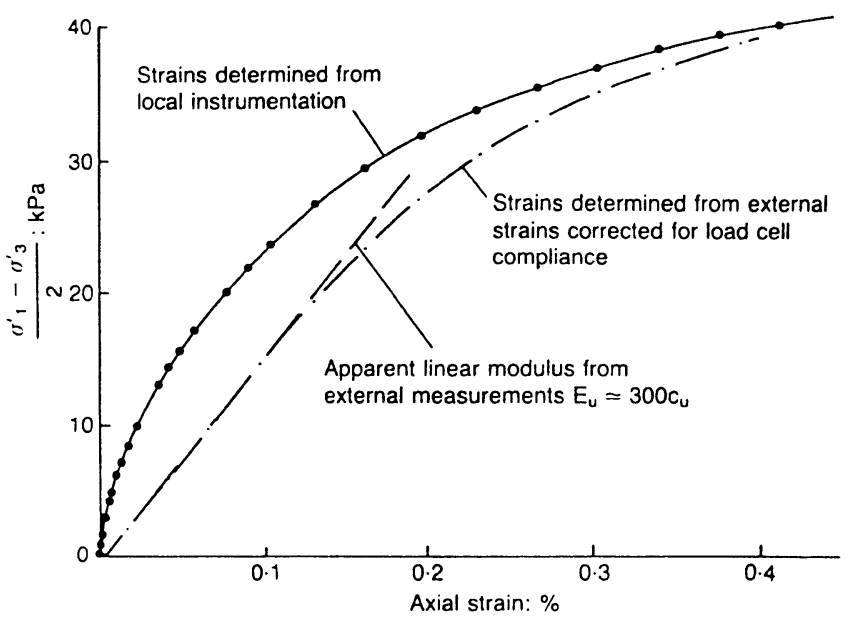

Fig.4 Stress - strain data (Jardine et al., 1984) tween the two hinges changes, as does the curvature of the LDTs. The recorded bending strains can be converted to axial strains once the LDTs have been calibrated. The resolution of this type of device has recently been improved ( $\mathrm{Ng}$ et al., 1995a) and it is capable of measuring strain as low as $10^{-7}$ with an accuracy of $10^{-5}$.

Figure 4 illustrates the stress -strain data from a test on a high quality intact London Clay sample. It is evident that the strains deduced from external measurements of deflection, even though corrected for load cell and apparatus compliance, gave much larger strains than values measured locally on the specimen. It is clear that the stress-strain behaviour of soils is highly non-linear over almost the entire strain range.

Figure 5 shows the measured normalized stiff ness $\left(E_{u} / c_{u}\right)$ versus axial strain $\left(\varepsilon_{L}\right)$ for a range of soils, reported by Jardine et al. (1984). The plots demonstrate the following main points:

(a) The stress - strain relationship for soils is highly non - linear over a wide range of strains.

(b) The tests on Chalk gave the highest normalized stiffness, equall to those of the low plasticity clay at small strains but exceeding them at strains above $0.01 \%$. The Chalk samples showed the most linear behaviour.

(c) The London Clay tests showed stiffness character istics similar to other heavily overconsolidated intact or remoulded low plasticity clays.

(d) The stiffness characteristics for the Ham river sand form a lower bound to all results reported in the diagram.

Figure 6 shows a way to illustrate the variation in shear stiffness $(G)$ with shear strain $(\gamma)$ for the Ital ian Vallericca Clay tested in a triaxial apparatus

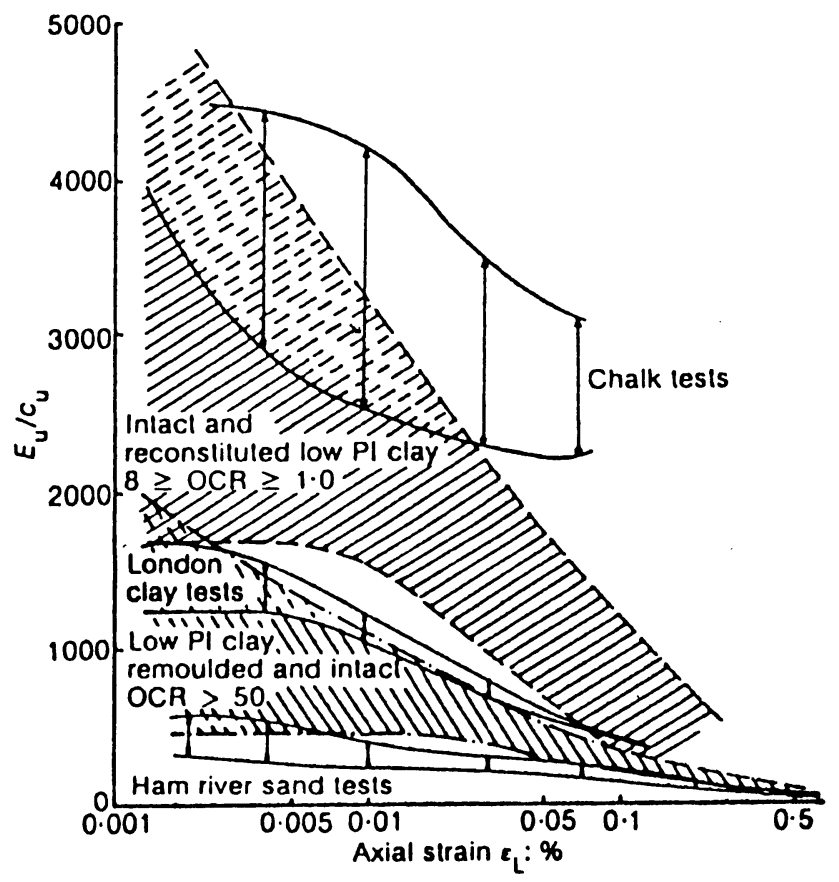

Fig.5 Summary of normalized stiffnesses (Jardine et al., 1984) 


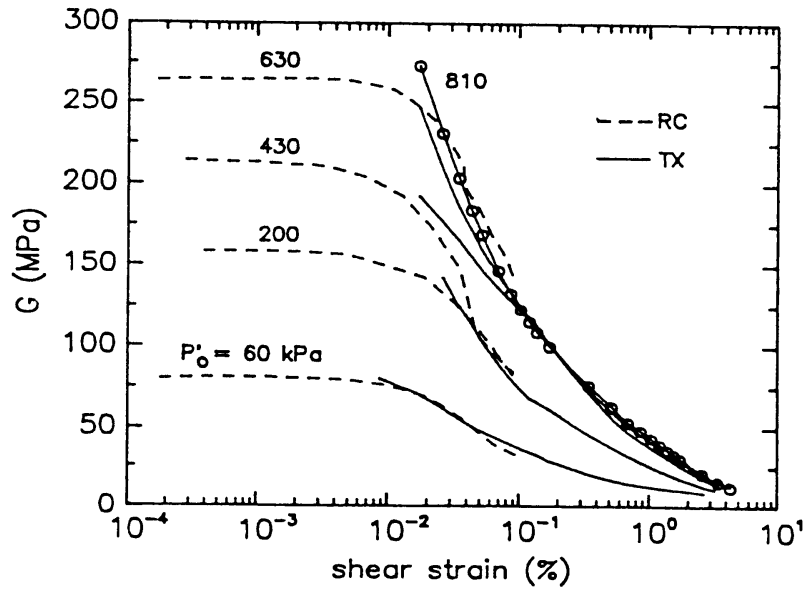

Fig.6 Comparison between resonance column (RC) and triaxial (TX) tests for a range of confining pressures: Vallericca Clay (Georgiannou et al., 1991)

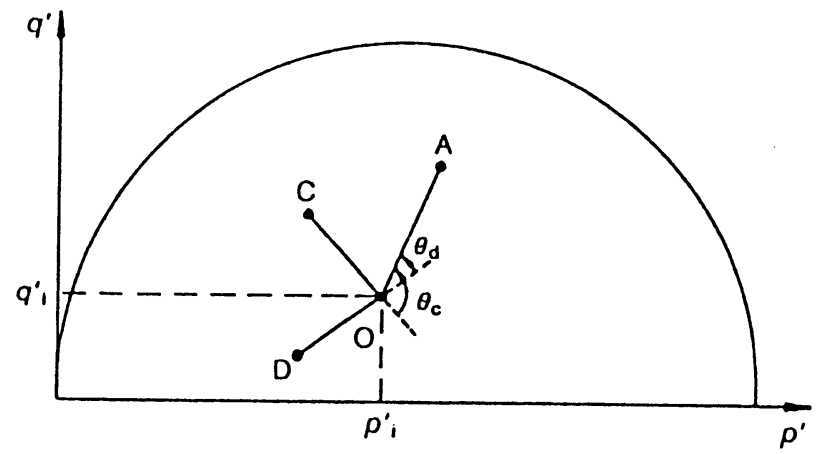

(a)

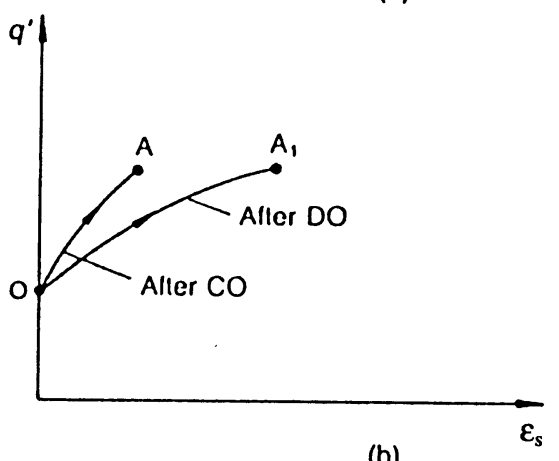

(b)

Fig.7 Effect of recent stress history on current stiff ness (Atkinson et al., 1990)

(TX) and a resonance column (RC). The effect of confining pressure on the measured shear stiffness $(G)$ is clearly shown.

\section{Recent stress history effects of overconsolidated soil}

It is now well understood that soil stiffness is highly non - linear, being greatest at the start of load ing when the increments of stress and strain are small. For a given soil at a given state with a particu lar stress history, the measured stiffness is often dif ferent for different stress paths such as compression or extension, drained or undrained, loading or un loading. Som (1968) observed that the compressibili ty of samples in oedometer tests was considerably re -
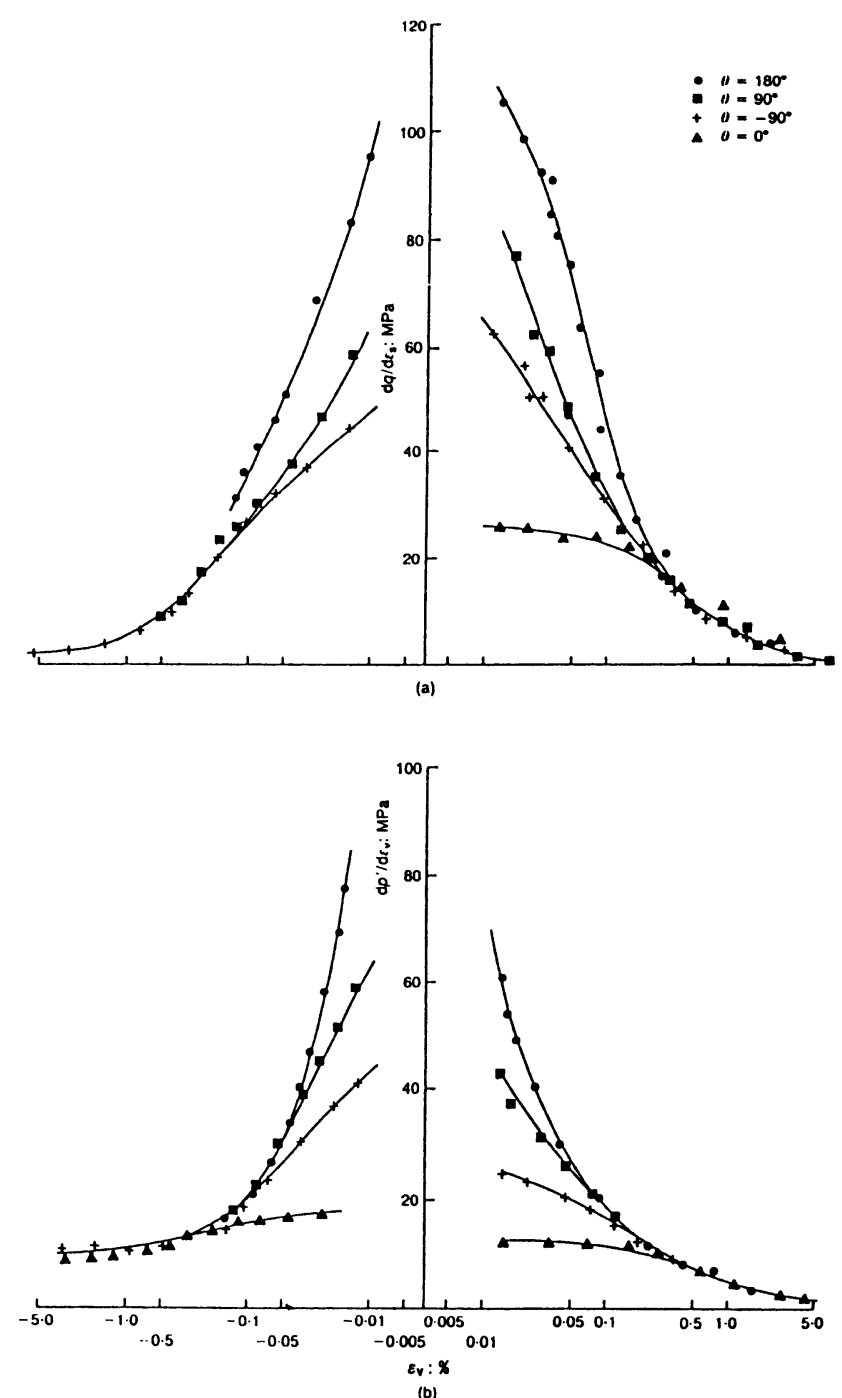

Fig.8 Stiffness of reconstituted London Clay measured in (a) constant p' tests; (b) constant q' tests (Atkinson et al., 1990)

duced (i.e., the stiffness was increased) following an extended period of costant loading. Atkinson (1973) found that the stiffness of samples in triaxial and plane strain tests was increased following a sudden change in the direction of the stress path. These have of ten been referred to as threshold effects. Atkinson et al. (1990) conducted a series of tests using reconsti tuted London Clay specimens to systematically study the previously observed threshold effects. They concluded that in addition to the overall stress history, which is best described by the overconsolidated ratio, the recent stress history, which includes either a sud den change in the direction of the stress path or a pe riod of time at a constant stress state, has a major ef fect on subsequent stiffness.

The effect of stress path rotation for loading paths which remain inside the state boundary is illus trated in Figure 7a. Samples brought to the same ini tial state $p^{\prime}{ }_{i}$ and $q^{\prime}{ }_{i}$ at $O$ along the different paths $\mathrm{CO}$ and DO are then loaded along the same path OA. At $\mathrm{O}$, the rotations of the stress paths relative to the new 
stress path $\mathrm{OA}$ are $\theta_{\mathrm{c}}$ and $\theta_{\mathrm{d}}$. Figure $7 \mathrm{~b}$ illustrates the stress - strain curves for the same loading path OA. Since the samples had identical states and over consolidation ratios at $\mathrm{O}$, and providing that they were both held at this state for equal periods of time, the difference in stiffness is attributable to the different stress path rotations.

Figure 8 shows tangent stiffnesses $\mathrm{dq} / \mathrm{d} \varepsilon_{\mathbf{s}}$ (shear) and $\mathrm{dp} / \mathrm{d} \varepsilon_{\mathrm{v}}$ (bulk) plotted versus the strains $\varepsilon_{\mathrm{s}}$ or $\varepsilon_{\mathrm{v}}$, respectively. It is clear that rotation of the stress path has a significant effect of on stiffness, particu larly at the start of the test. At small strains of the order of $0.01 \%$, the stiffness for $\theta=180^{\circ}$ is approxi mately an order of magnitude larger than the corre sponding stiffness for $\theta=0^{\circ}$, but at strains of the or der of $0.5 \%$ the differences have been largely removed. Stiffnesses for $\theta=+/-90^{\circ}$ fall between those for $\theta=$ $0^{\circ}$ and $180^{\circ}$. All these clearly demonstrate that the stress - strain behaviour of overconsolidated soil is non-linear and the stiffness depends on the current state, the overconsolidation ratio and the recent stress history.

\section{MATHEMATICAL SOIL MODELS}

\section{Introduction}

A most important development in the campaign to predict the stress-strain behaviour of soil was the development at Cambridge University of a group of plasticity models, introduced by Schofield and Wroth (1968) in their most philosophical and useful book "Critical State Soil Mechanics". The critical state framework, which was formulated so elegantly by the Cambridge soil mechanics group under the late Pro fessor Roscoe, has provided a coherence which the subject previously lacked. It has also provided a logi cal framework for incorporating theories of plastici ty, yield and flow for the mathematical modelling of soil behaviour (i.e., Cam - clay models). Over the last twenty years, critical state soil mechanics has been widely taught and increasingly applied to the so lution of engineering problems (Burland, 1990). For many soil models, an explicit state boundary surface is essential for modelling soil behaviour. The state boundary surface, which is called the stable state boundary surface (SSBS), is used to separate possi ble from impossible states and it is usually assumed that for states inside the surface, deformations are elastic and for states on the surface, deformations are elasto-plastic, so that the state boundary surface is a yield surface.

Traditionally, the behaviour within the yield sur face has been assumed to be either rigid linear elastic or non-linear elastic. The shortcomings of such as sumptions are now widely appreciated, especially for predicting the behaviour of foundations constructed in stiff clays and dense sands where small strain de formations are expected under normal serviceability conditions. It is thus useful to adopt a framework that distinguishes the main phases of soil pre-failure

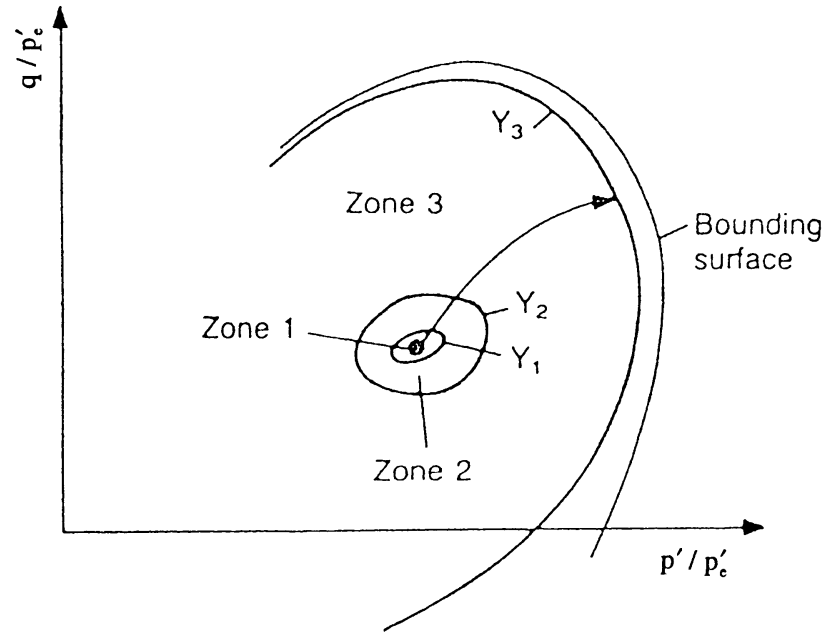

Fig.9 Regions of small strain and high stiffness at three states of stress history (Jardine, 1994)

behaviour in a more appropriate manner (Jardine, 1994).

\section{Multiple kinematic yield surface models}

Following the ideas of Mroz (1967), some researchers have proposed multiple kinematic yield surfaces (Jardine, 1985; Al - Tabba and Wood, 1989) to closely describe the observed and the recently understood elasto - plastic behaviour of soils within the large - scale yield surface. Figure 9 shows the basic elements of the modelling scheme (Jardine, 1994). The large - scale yield surface is represented by the $\mathrm{Y}_{3}$ locus. Only small to moderate strains are developed by stress changes that remain within the $\mathrm{Y}_{3}$ surface; the tangent stiffness of soil changes abruptly when a probing stress path reaches the surface. In fact, this surface denotes the current bounding surface which cannot be crossed by undrained tests. The more ex tensive SSBS lies outside this current surface, which can only be reached by following drained probing stress paths in which large volume strains are devel oped. The current effective stress point is surrounded by two inner sub-yield surfaces, called $\mathrm{Y}_{1}$ and $\mathrm{Y}_{2}$, which move with the point (i.e., are kinematic). For calculation purposes, the strains are computed from origins defined at the initial stress point. The $\mathrm{Y}_{3}$ sur face remains relatively immobile and is only affected by comparatively large strain events. The $\mathrm{Y}_{1}$ surface represents the limits to the region over which the soil response is linearly elastic when loaded. When stress changes are applied which cross the initial boundary, the $\mathrm{Y}_{1}$ region is dragged with the stress point and elastic behaviour is only observed when the stress path direction alters so as to re - enter the $Y_{1}$ region. Once the $Y_{1}$ region is engaged, the response is initial ly hysteretic and non-linear and some insignificant plastic strains are predicted. Appreciable plastic straining is delayed until the stress path engages the surrounding $\mathrm{Y}_{2}$ surface. The plastic yielding experienced at this point may be expressed by a marked shift in the directions of the strain increment vector. 
A further feature of the $\mathrm{Y}_{2}$ surface is that it defines the threshold at which drained or undrained cycling starts to significantly affect the soil.

As the stress path further increases, heading to wards the $\mathrm{Y}_{3}$ surface, substantial plastic deformation develops. As before, a sharp change in stress path direction can cause the stress point to re - enter the $Y_{1}$ and $\mathrm{Y}_{2}$ regions.

\section{The Brick model}

An alternative but more elegant way of thinking of the concept of multiple kinematic yield surfaces for modelling the non-linear stress-strain behaviour of soil and the recent stress history effect was developed by Simpson (1992), who presented a novel way of modelling soils: "bricks on strings".

After careful study of laboratory test results of soil behaviour at small strains (see Figure 8), Simpson used a physical analogue, a man pulling a num ber of bricks inside a room, to illustrate the idea of modelling this observed soil behaviour. Simpson imagined a man walking around a room and pulling behind him a series of bricks, each on a separate in extensible string. Some possible paths for the man and strings are shown in Figure 10. If he walks continuously in one direction, the bricks line up behind and follow him (see Figure 10a). This is an analogy for the plastic behaviour of soil. If the man turns back (Figure 10b), the bricks initially do not move; then those on shorter strings start to move, gradually followed by those on longer strings (Figure 10c). This analogy represents soil behaviour when its stress or strain path rotates $180^{\circ}$. If the man turns through $90^{\circ}$, the bricks initially keep moving in their previous direction but gradually swing round behind him (Figure 10d). The similarity between the man

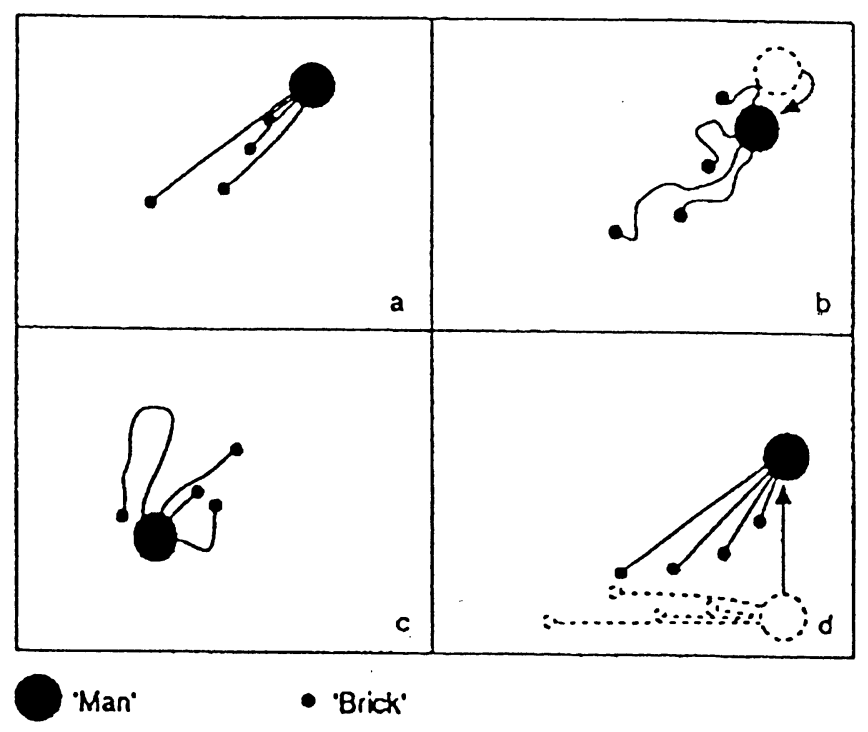

Fig.10 The analogy - a man pulling bricks around a room (after Simpson, 1992) with his bricks and soil behaviour is obvious.

Simpson regarded the "room" as strain space and used the movement of the "man" to represent the total strain of a soil element in the chosen strain space. Each brick represents a proportion of the soil element. The movement of each brick represents the plastic strain undergone by that portion of the soil el ement. The elastic strain of the element is given by the difference between the movement of the common point (the man) and the sum of the movements of the bricks, each weighted in accordance with the proportion of soil material it represents.

Figure 11 shows an "S-shaped" curve which has been idealized for a number of bricks. This type of "S - shaped" curve is commonly used to show the way in which stiffness of soils decreases with increasing shear strains. In the figure, the vertical axis is the normalized tangent shear stiffness $\left(G_{t} / s^{\prime}\right)$. The $\gamma-$ abscissa of each brick is the string length, i.e., the maximum elastic shear strain that each portion of the soil element can undergo. The steps shown in the figure indicate the points at which strings become taut and a proportion of the soil element becomes plastic. The proportion of soil which each brick represents is given by $h_{i} / h_{o}$. At large strains, the " $S$ shaped" curve reaches the horizontal axis. This im plies that the soil mass has failed. In the model, it is assumed that the soil is homogeneous and isotropic, and only elastic strain causes a change in stress.

A number of assumptions which are well - known in soil mechanics are incorporated in the model as follows:

(a) The elastic volumetric stiffness is assumed proportional to the current mean normal stress (s') and the elastic behaviour of soil at very small strains is governed by a new proportional constant iota ( $\iota$ ) as shown in Figure 12. The lambda $(\lambda)$ line is the vir gin consolidation line whereas the kappa $(\kappa)$ line refers to unloading/reloading situations in $\mathrm{v}-\ln s$ ' space. It should be noted that the $\lambda$ and $\kappa$ shown in the figure are similar in principle but different in numerical values to the conventional $\lambda$ and $\kappa$ values

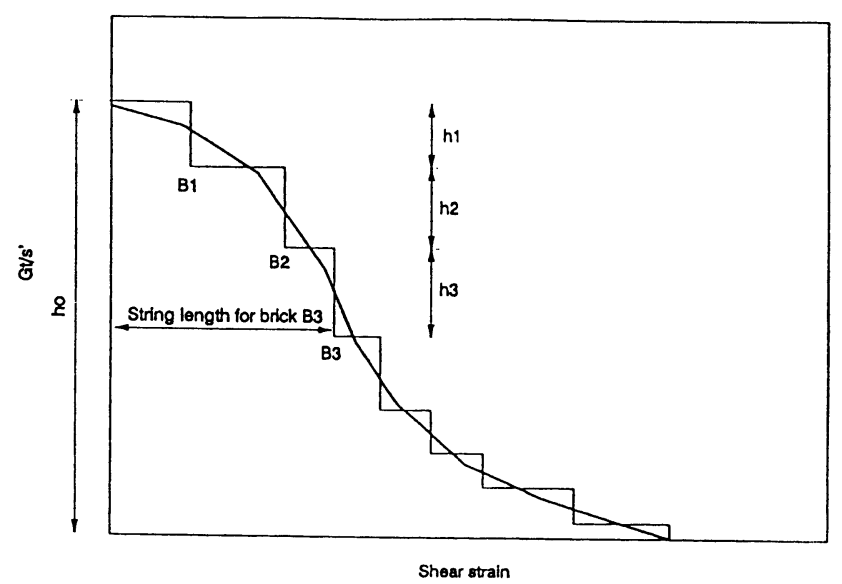

Fig.11 Idealization of the "S-shaped" stiffnessstrain curve for the Brick model 


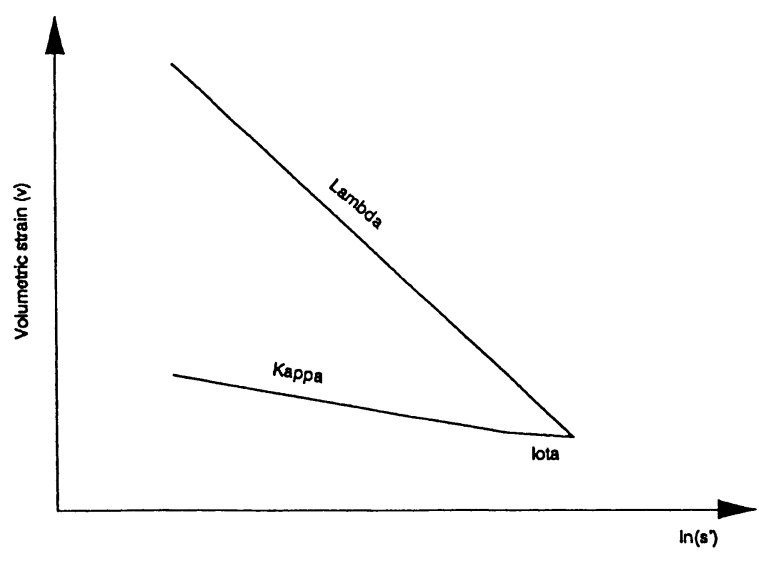

Fig. 12 Proportional constants for the Brick model

used in the Cam - Clay models (Schofield and Wroth, 1968).

(b) For a plane strain formulation, the elastic shear stiffness can be derived from elastic volumetric stiff ness with the assumption of a constant Poisson's ratio. This leads to the basic elastic stress - strain rela tionship for the Brick model given by

$$
\left[\begin{array}{c}
\delta \mathbf{s}^{\prime} \\
\delta \mathrm{t}
\end{array}\right]=\frac{\mathbf{s}^{\prime}}{\iota}\left[\begin{array}{cc}
1 & 0 \\
0 & \left(1-2 \mathrm{u}^{\prime}\right)
\end{array}\right]\left[\begin{array}{l}
\delta \mathrm{v}_{\mathrm{e}} \\
\delta \gamma_{\mathrm{e}}
\end{array}\right]
$$

(c) It is further assumed that during normal consoli dation, an increase in mean normal stress ( $\mathrm{s}^{\prime}$ ) makes available an extra capacity for elastic volumetric strain. This assumption is based on the fact that when normal stress on a frictional body is increased, its ability to strain elastically (both normal and shear) without slip is also enhanced. This gives rise to the log - linear compression and swelling lines that are often clearly displayed by soils and that are represented by the parameters $\lambda$ and $\kappa$ in the Cam clay models. In the Brick model, the additional elas tic volumetric capacity for normal compression is given by

$$
\delta \mathbf{v}_{\mathbf{c}}=\left(\frac{\iota}{\lambda}\right) \delta \mathrm{v}
$$

and during unloading and reloading, equation (2) is modified to

$$
\delta \mathrm{v}_{\mathrm{c}}=\left(\frac{\iota}{\kappa}\right) \delta \mathrm{v}
$$

Similarly, additional capacity for elastic shear is also assumed and given by the following formula:

$$
\delta \mathrm{v}_{\mathrm{c}}=\frac{1}{\left(1-2 \mathrm{u}^{\prime}\right)}\left(\frac{\mathrm{t}}{\mathrm{s}^{\prime}}\right) \delta \mathrm{v}_{\mathrm{c}}
$$

The effect of this assumption is to ensure radial straight lines occur in $\left(s^{\prime}, t\right)$ stress space during anisotropic consolidation, i.e., $\mathrm{dt} / \mathrm{ds}=\mathrm{t} / \mathrm{s}^{\prime}$. By com bining equations $1-4$, and by considering the strain history and location of the "man", the basic stress strain equation (3) becomes

$$
\left[\begin{array}{c}
\delta \mathrm{s}^{\prime} \\
\delta \mathrm{t}
\end{array}\right]=\left[\begin{array}{ll}
\mathrm{f} & 0 \\
0 & \mathrm{~F}
\end{array}\right]\left[\begin{array}{l}
\delta \mathrm{v}_{\mathrm{e}} \\
\delta \gamma_{\mathrm{e}}
\end{array}\right]
$$

where $f$ and $F$ are two non-linear functions which cannot be explicitly expressed in analytical form.

(d) Soil stiffness at small strains varying linearly with the logarithm of OCR has recently been reported by some researchers (Viggiani, 1992). This observed soil behaviour is incorporated in the model by introducing a multiplier equal to $\left\{1+\beta\left(\mathrm{v}-\mathrm{v}_{\mathrm{o}}-\lambda \ln \left(\mathrm{s}^{\prime} / \mathrm{s}^{\prime} \mathrm{o}\right)\right\}\right.$ to the soil stiffness, where vo and s'o indicate the ini tial state of the soil relative to which isotropic consol idation is to be measured. Normally, this state represents a slurry. For normally consolidated soils, $\beta$ $=0$. More details of the model are given by Simpson (1992).

Conventional parameters for numerical modelling such as $\phi^{\prime}$ and $\mathrm{K}_{\mathrm{o}}$ are not required for the model, but follow automatically from the brick concept and as sumptions described.

\section{IMPORTANCE OF GEOLOGICAL INFOR - MATION TO THE ANALYSIS OF AN UR - BAN DEEP EXCAVATION}

\section{The development}

The Lion Yard site is situated in the city centre of Cambridge and it is approximately $65 \mathrm{~m}$ by $45 \mathrm{~m}$ on plan. The structure consists of a three-level under ground carpark beneath a five-storey hotel and is supported on large diameter under-reamed bored piles founded $30 \mathrm{~m}$ below ground level in the Gault Clay. A cross - section of the site is shown in Figure 13. The $10-\mathrm{m}$-deep excavation is retained by a $17-\mathrm{m}$ - deep perimeter concrete diaphragm wall $0.6 \mathrm{~m}$ thick.

Efficient design in geotechnical engineering is not easy. Nearly every geotechnical engineer must make some assumptions and he runs the risk of encountering surprises. These circumstances are the inevitable result of dealing with natural materials such as soil and rock. Field monitoring is therefore necessary to provide a means by which the geotechnical engineer can verify the design assumptions and the contractor can execute the work with safety and economy. More importantly, the field data may also be assembled in to a comprehensive case record that is then available for use when checking the validity of any analytical and numerical models. The ongoing process of back - analysis can help to refine and improve our under standing, which in turn provides guidance for future designs. Without field monitoring and back - analy sis to provide feedback, it is not possible to assess how conservative the design of a structure is. This is particularly so in geotechnics, where the effects of soil-structure interaction are still being explored. Figure 14 illustrates the relationship between design, construction and back - analysis.

In order to verify the design assumptions, to monitor the performance of the 10-m-deep excavation at Lion Yard and to provide valuable data for back - 


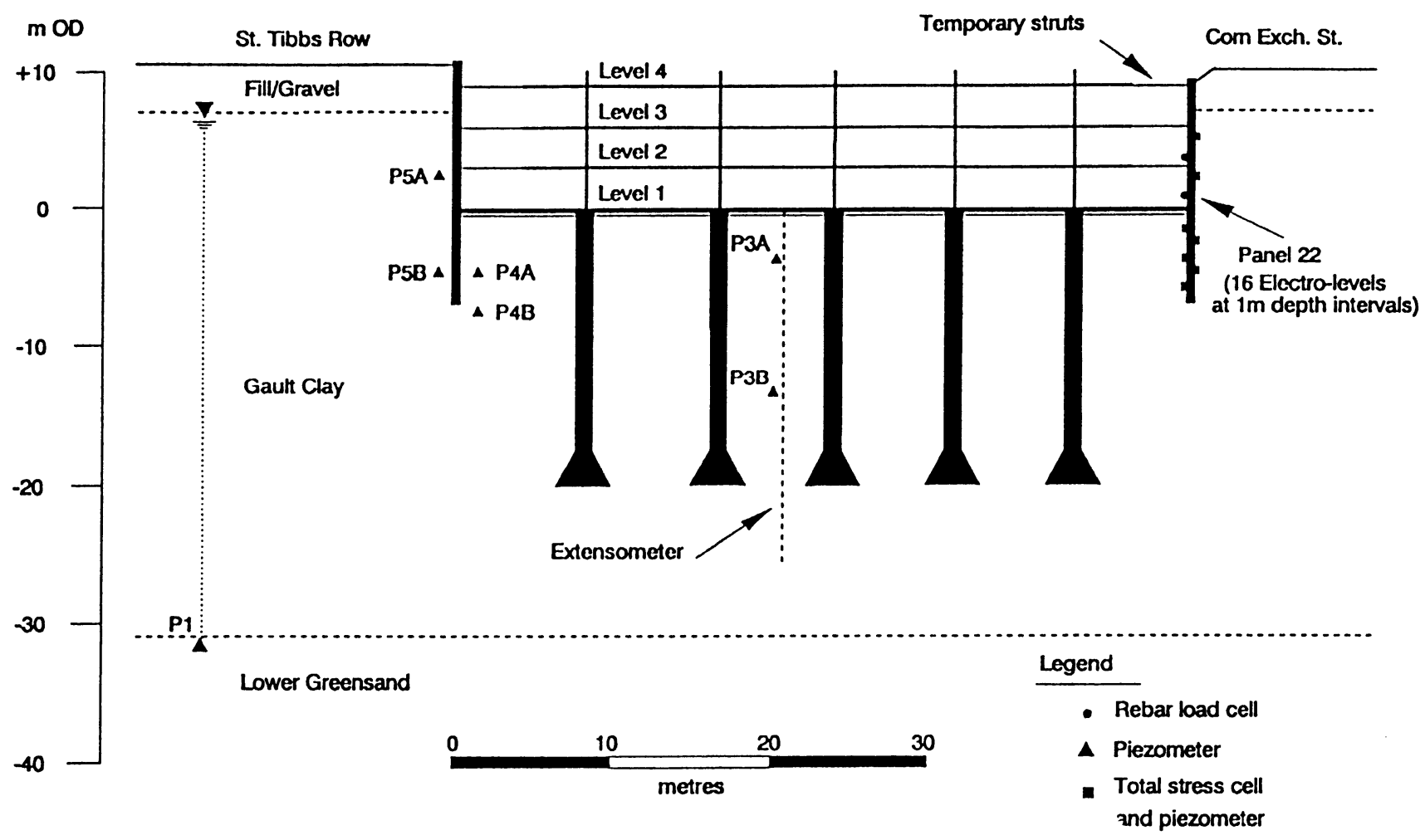

Fig.13 Cross section of the site

analysis, various instruments were installed on site. Full details of the instrumentation together with in terpreted results are reported by $\mathrm{Ng}(1992)$.

\section{Geology and soil properties of the site}

Folding, uplifting and subsequent erosion at the end of the Jurassic or in the early part of the Creta ceous period gave rise to an unconformity, so that the earliest Cretaceous formation, the Lower Greensand, rests on Kimmeridge clay in some places, and Coral lian in others (Chatwin, 1961; Worssam and Taylor, 1969). The Lower Greensand was deposited in shal low water and subsequently the Gault clay was laid down as a result of a widespread marine incursion that spanned the Middle and Upper Albian stages. The conditions were not uniform throughout the peri od of deposition and so the Gault contains several beds of different lithology. At the end of Gault times, there was a temporary halt in deposition, accompa-

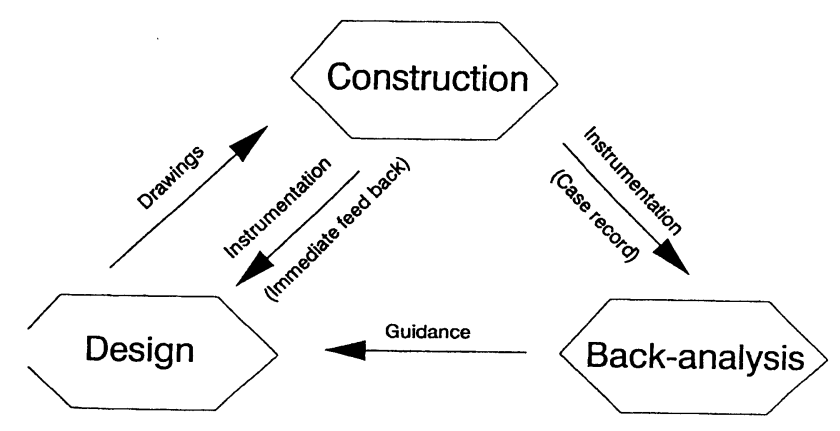

Fig.14 The inter - relationships between Design, Con struction and Back - analysis nied by submarine erosion and reworking of sediments on the sea floor.

Following the deposition of the Gault, the Chalk was laid down as the sea water cleared and the land areas dwindled so that less and less terrigenous sed iment became available. During the Tertiary and Quaternary periods, uplift and extensive erosion took place and eventually produced the present landscape. An estimated $200 \mathrm{~m}$ to $400 \mathrm{~m}$ of Chalk has since been eroded.

At least two Pleistocene ice sheets passed over the Cambridge area (Chatwin, 1961; Worssam and Tay lor, 1969). A subsequent interval of warm - tempera ture inter - glacial conditions is indicated by some of the higher river terrace deposits, followed once more by Arctic conditions during the last glaciation. Sub sequently, the lowest river terrace deposits were formed.

In the Cambridge area, the thickness of Gault varies between $27 \mathrm{~m}$ and $42 \mathrm{~m}$. At Lion Yard, a 38-m thickness of Gault was found during the installation of a standpipe piezometer in the Lower Greensand. The soil profile obtained during site investigation is shown in Figure 15. In general, groundwater condi tions are approximately hydrostatic below a level of about $+7.0 \mathrm{~m}$ OD (i.e., about 3 to $3.5 \mathrm{~m}$ below exist ing ground level).

The Gault Clay in Cambridge is highly calcare ous, containing up to $30 \%$ by weight of calcium car bonate (Worssam and Taylor, 1969). A similar re sult $(27.5 \%)$ was found in samples taken from Lion Yard. The Gault in its natural state is heavily over consolidated, with a natural water content close to the 


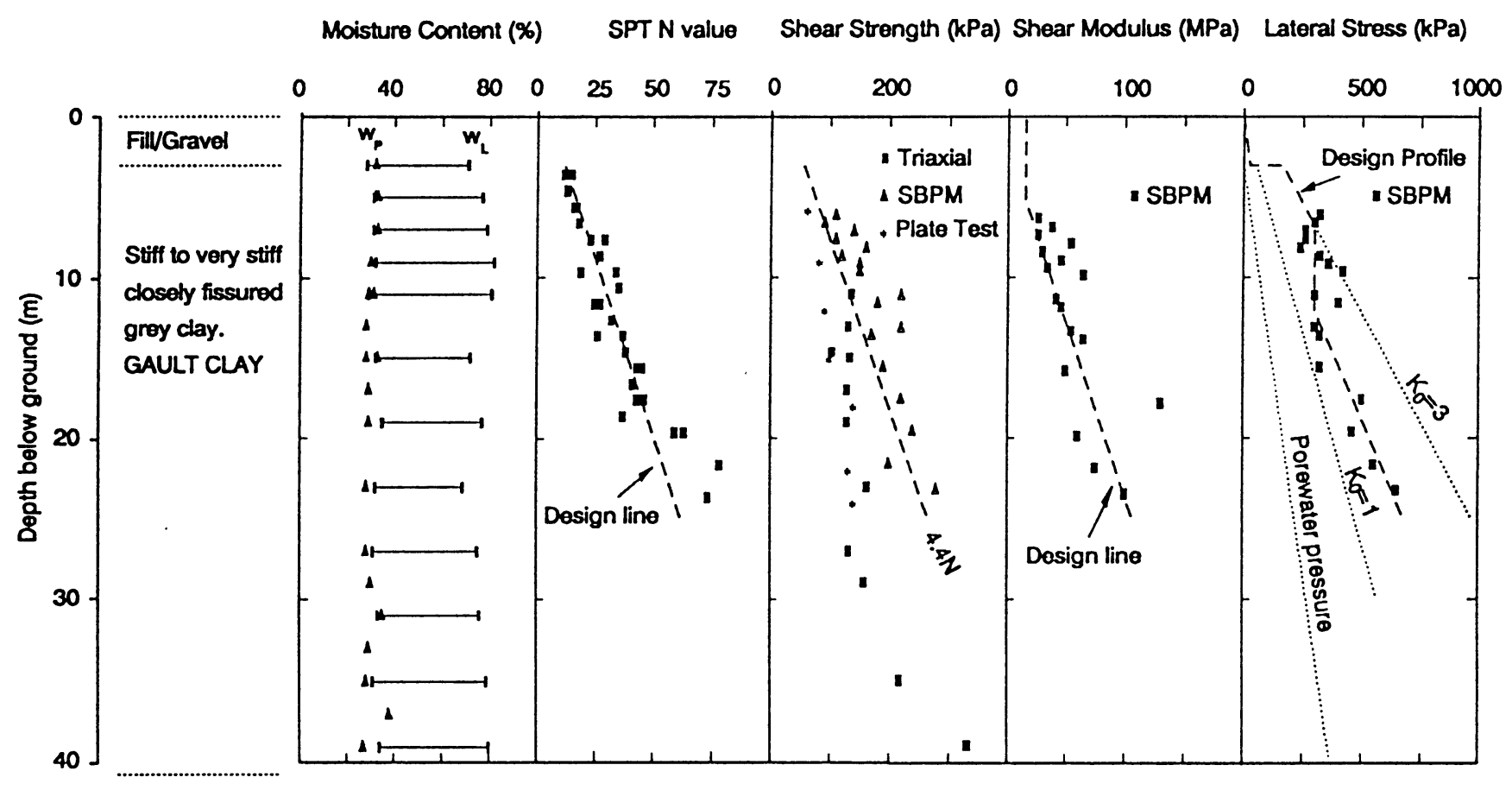

Fig.15 Soil profile and geotechnical parameters

plastic limit. It consists of stiff to hard silty grey clay of high plasticity. The clay is laminated with closely spaced fissures and joints. The top few metres of clay. show signs of weathering such as cryoturbation. Hard nodules of phosphatized marl are scattered through the clay.

Use of geotechnical information to assess the initial stress in the ground

It is extremely difficult to assess initial horizon tal stresses in the ground correctly, but they are one of the most important parameters necessary for analysis and design of soil structures. Reloading on top of a clay deposit has a dominant effect on vertical effective stress but has only a relatively small effect on horizontal effective stress, as illustrated by many researchers (Burland et al., 1979; Simpson et al., 1979). They allowed for the effects of reloading by assuming isotropic elastic behaviour and using the equation given below:

$$
\frac{\Delta \sigma^{\prime} h}{\Delta \sigma^{\prime} v}=\frac{u^{\prime}}{1-u^{\prime}}
$$

Simpson et al. (1979) show that the ratios of $\left(\Delta \sigma^{\prime}{ }_{h}\right.$ $/ \Delta \sigma_{v}^{\prime}$ ) due to reloading were 0.18 and 0.33 for isotrop ic and anisotropic assumptions, respectively, for London clay. Similar results are expected for the Gault. Clearly, reloading has a relatively small ef fect on $\sigma^{\prime}{ }_{h}$ and therefore leads to a reduction in $\mathrm{K}_{\mathrm{o}}$, especially in the top few metres of clay.

As described previously, the geological history is not simple at Lion Yard. The Gault clay has been reloaded by gravel and fill after the erosion of the Chalk. A simple calculation indicates that at $1 \mathrm{~m}$ be low the top surface of Gault clay, an initial $K_{0}$ value of 3.0 prior to redeposition will be reduced to less than 1.0 as a result of a $3-\mathrm{m}$ - thick redeposition. This is substantially different from the in - situ self - bor ing pressuremeter measurements (șee Figure 15). The results of these tests suggest that very high ini tial horizontal stresses are present in the upper $7 \mathrm{~m}$ of the Gault clay at Lion Yard, corresponding to $\mathrm{K}_{\mathrm{o}}$ val ues ranging from 1.5 to 3.5 when related to the cur rent vertical effective stresses. This upper part of the clay is the most relevant, since the entire basement is located within $10 \mathrm{~m}$ below ground level. It is thus im portant to compare the results of the pressuremeter testing with other tests, and with semi - empirical and theoretical calculations.

Figure 16 shows the variation of total horizontal stresses with depth measured in Gault Clay at Lion Yard and Madingley (Powell, 1990), and estimations using the semi - empirical correlation originally proposed by Schmidt (1966), $\mathrm{K}_{\mathrm{o}}=\mathrm{K}_{\text {onc }} \mathrm{OCR}^{\mathrm{m}}$, where $\mathrm{m}=1$. $2 \sin \phi^{\prime}$. Laboratory test results $\left(\phi^{\prime}=24^{\circ}\right)$ on reconsti tuted specimens $(\mathrm{Ng}, 1992)$ have been used in the cal culation. Since the maximum preconsolidation pres sure at Lion Yard is not known, a range of possible preconsolidation pressures $(2000 \mathrm{kPa}$ to $4000 \mathrm{kPa})$ has been considered. The Madingley site is situated about $4 \mathrm{~km}$ west of Lion Yard and the top of the Gault clay is at the ground surface, i.e., no reloading by gravel has occurred. Figure $16 \mathrm{~b}$ shows the corresponding distribution of $\mathrm{K}_{\mathrm{o}}$ with depth. It should be noted that prior to reloading, the top few metres of the clay was in a state of passive failure with $K_{p}$ value of 3.5 , a value based on the results of laboratory tests $\left(\phi^{\prime}=34^{\circ}\right)$ on undisturbed block samples taken from the site $(\mathrm{Ng}, 1992)$.

It can be seen from Figure $16 \mathrm{a}$ that the measured 


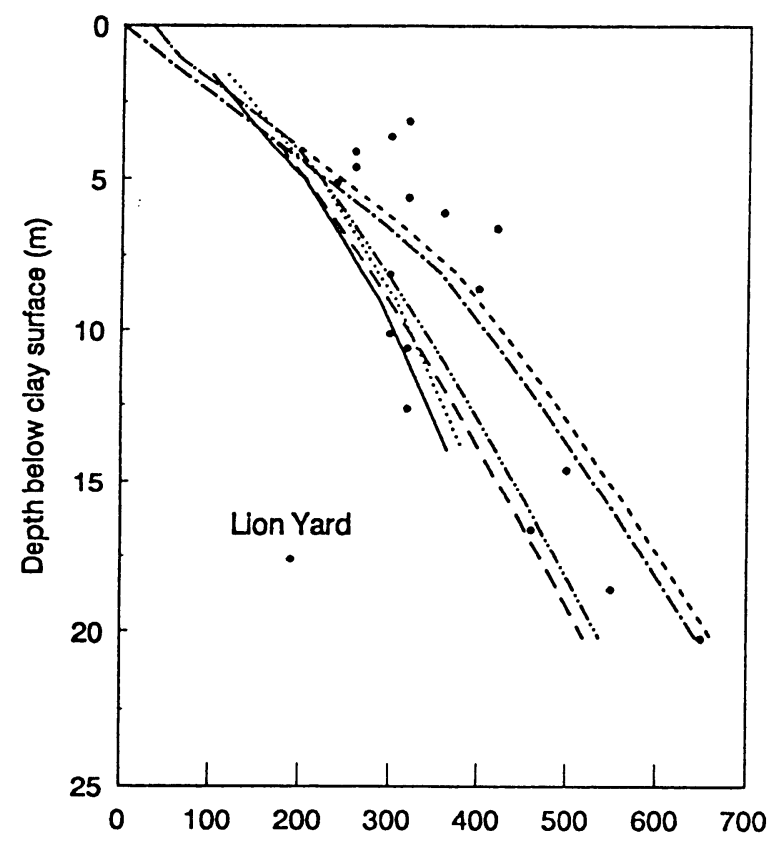

(a) Total horizontal stress $(\mathrm{kPa})$

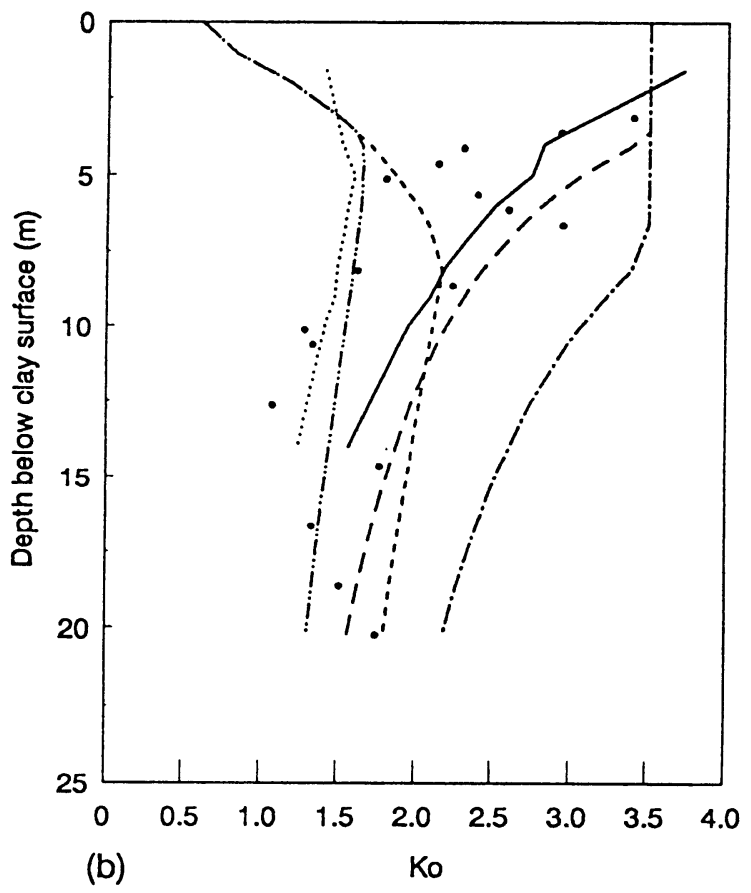

(b)

Madingley Madingley (reloading) Schmidt (2000 kPa) Schmidt (2000 kPa, reloading) Schmidt (4000 kPa) Schmidt (4000 kPa, reloading)

Fig.16 Comparison of the measured initial horizontal stresses and $\mathrm{K}_{\mathrm{o}}$ at Lion Yard and Madingley

horizontal stresses at Lion Yard are substantially higher than the measurements using a self - boring pressuremeter at Madingley for the top $7 \mathrm{~m}$ of clay, even if the lateral stresses are adjusted to allow for the assumed effects of reloading by a 3-m thickness of gravel. Similarly, the measured values at Lion Yard are significantly higher than the estimated horizontal stresses using Schmidt's semi - empirical correlation for the possible range of preconsolidation pressures considered. The simplified geological history of Lion Yard has also been simulated numerically using the Brick model (Simpson, 1992). The results of the sim ulation agree with the predictions using Schmidt's correlation and the measurements at Madingley if reloading by gravel is considered. More details of the simulation are given by $\mathrm{Ng}$ (1992). Thus, it is be lieved that the initial horizontal stresses in the ground are likely to have been overestimated by the self - boring pressuremeter tests at Lion Yard.

\section{Simulation of the geological history at Lion Yard}

Correct modelling of the initial stress conditions in the ground and wall installation effects is vital for the back-analysis of the main excavation at Lion Yard (Ng, 1992; Ng et al., 1995b). Thus, numerical modelling of the main excavation was started by simulating the geological history of the site, followed by modelling the diaphragm wall installation effect and finally the three stages of excavation at the three levels of the underground carpark.

To model the initial $\mathrm{K}_{\mathrm{o}}$ condition at this site, an additional analysis stage in the numerical simulation procedure was set up to mimic the geological history

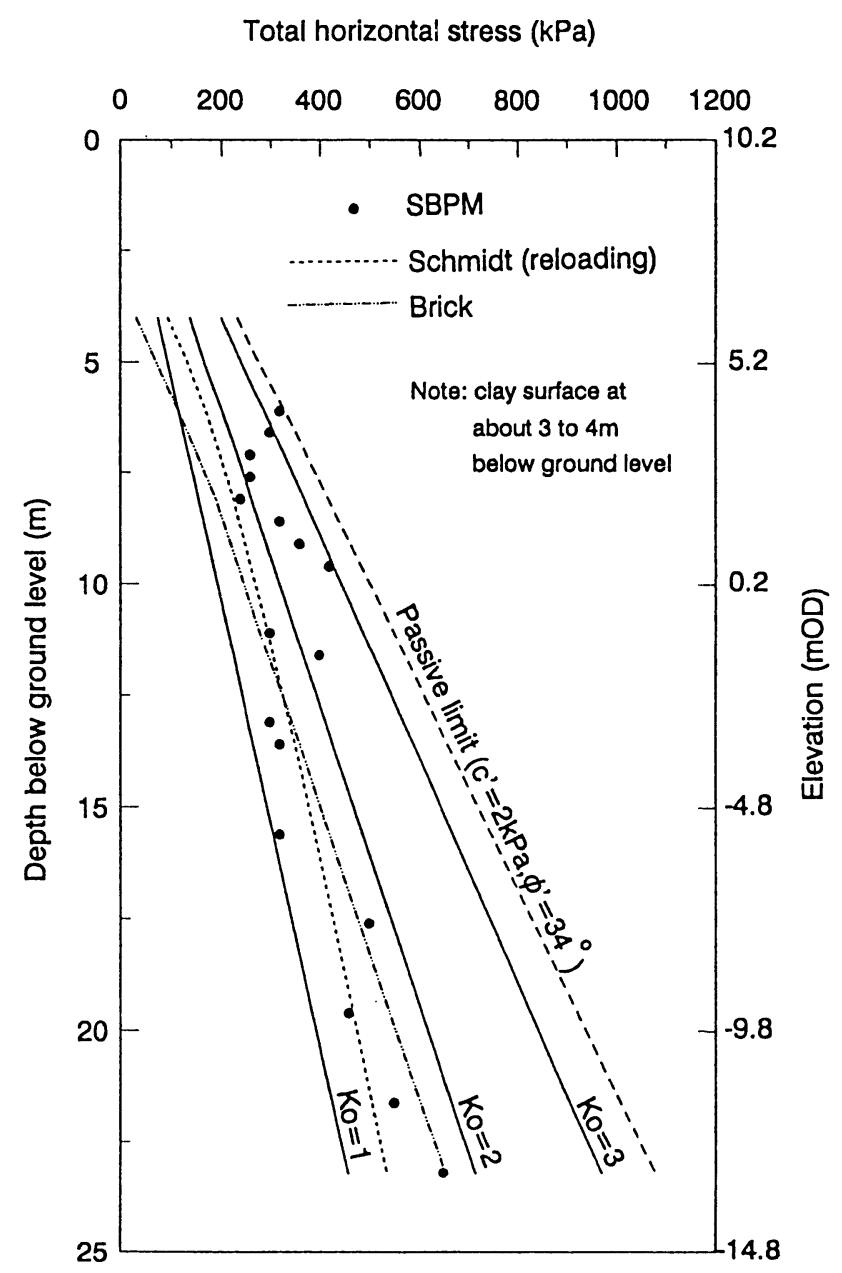

Fig.17 Initial stresses in the ground 


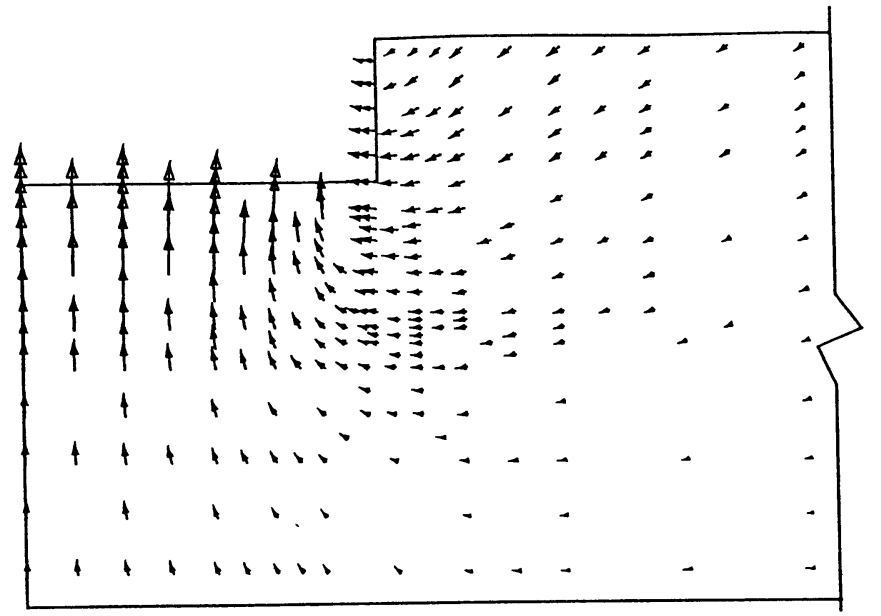

Fig.18 Displacement vectors at the end of excavation

of the site by consolidating the Gault clay one-di mensionally to its estimated preconsolidation pres sure, followed by erosion, and then reloading by made ground and gravel. The computed initial hori zontal stresses are compared with field measurements (SBPM) and other empirical predictions in Figure 17. Based on these comparisons and the geological study, it is believed that the initial $\mathrm{K}_{\mathrm{o}}$ values varied between 1.0 and 2.0 for the top $7 \mathrm{~m}$ of the clay.

\section{Comparison of the measured performance and the} computed results

Figures 18 and 19 show the computed general ground deformation vectors and shear strain contours around the site at the end of main excavation, respectively. Due to vertical stress relief inside the site, soil on the retained side moved towards the ex cavation whereas the soil underneath the excavation heaved upwards as depicted in Figure 18.

It can be seen in Figure 19 that the shear strains developed around the excavation were small and gen erally less than $0.3 \%$, except in front of the wall just below the final excavated level where the soil was yielding. A similar pattern and magnitude of shear strains has been predicted by Arup Geotechnics for the multi-propped excavation in London clay at the British Library at Euston (Atkinson and Sallfors, 1991). These indicate that the moduli adopted for any calculations based on the theory of linear elasticity should be appropriate for the average small strain level anticipated during main excavation. By study ing the strains developed around excavations, an ap propriate soil stiffness corresponding to the average small strains can be selected for design from laboratory test results ( $\mathrm{Ng}$ et al., 1995c).

Figure 20 shows the comparison between the computed and measured displacements of the wall for the three stages of main excavation. At the first stage of excavation, the wall behaved essentially as a cantilever wall with only small propping effects at the top of the wall. This was because the installation of some of the top level props had not been completed

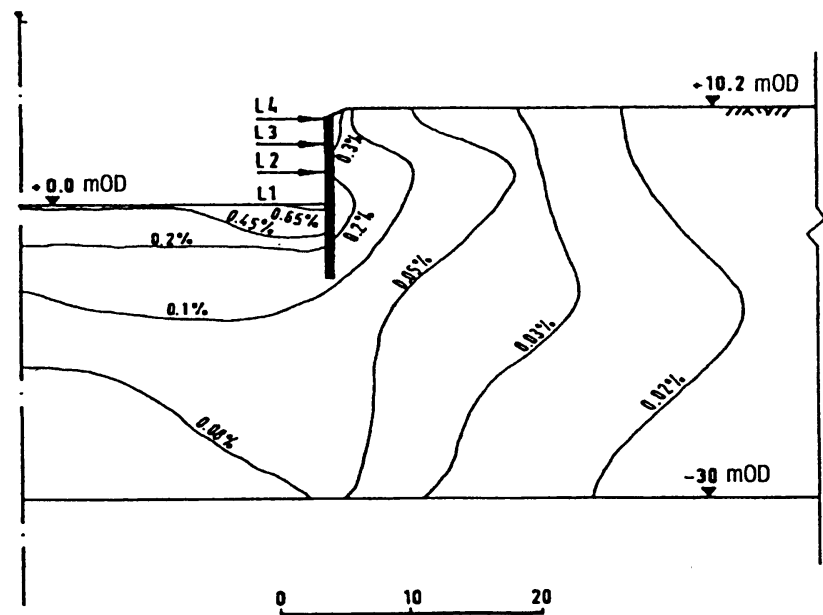

Fig.19 Shear strains around the site at the end of ex cavation

before the start of the excavation. An allowance was made in the analysis by using a factored prop stiff ness.

During the subsequent two stages of excavation, the deflected profiles of the wall were typical for a multi-propped wall constructed in stiff clay, i.e., deep - seated inward movements occurred (Burland et al., 1979). Generally, the predicted and measured de flections of the wall are in good agreement although the Brick model overpredicted the lateral inward movement in the region of the toe, which resulted in smaller predicted wall curvature than the measured value.

Inward toe movement as a result of vertical stress relief is clearly depicted in Figure 20 by the field measurements and numerical predictions. The conventional approach of deducing wall displacements from field data by assuming fixity at the toe would have underestimated the true wall deformation.

A comparison of the measured mean and calcu lated prop forces at the final stage of excavation is shown in Figure 21. The predictions appear to corre spond reasonably well with the field observations de spite the large overprediction of prop force at L3. This is probably because the fixed end moment provided by the concrete column at the top of the wall was ignored in the analysis. The introduction of a negative moment at the top of the wall would have re sulted in a smaller predicted prop force at L3. Good agreement between the measured and computed prop forces is important as this increases the confidence in the computed earth pressures, which are of course in force equilibrium with the predicted prop forces. This seems to imply that the estimated initial stress es in the ground, based on geological information and numerical simulation, are likely to be correct.

\section{CONCLUSIONS}

a) Nearly all engineering structures are supported in some way on natural earth materials, and this inevitably creates a connection between geological conditions and foundation analysis, design and con- 


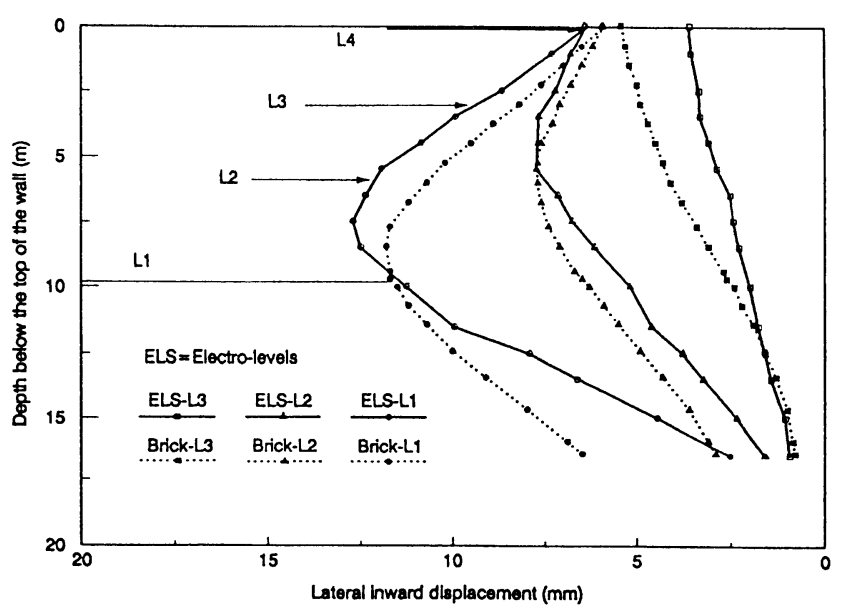

Fig.20 Comparison of the measured and computed displacements of the wall during excavation

struction. This implies an inevitable interaction be tween geologists and geotechnical engineers. Since the approach of the two parties to the same problem is psychologically different, understanding and cooperation between the two are essential for the success of a project. For geotechnical engineers, some basic knowledge of geology, and for geologists, some understanding of mechanical behaviour of soils, will certainly help to build up a valuable partnership to the mutual benefit of both geology and geotechnical engineering.

b) The stiffness of most soils decreases as strain in creases and the stiffness at small strains is strongly dependent on the current state and the recent stress or strain history of each soil element.

c) The development of mathematical models in geotechnical engineering has been very rapid. Cur rently, constitutive laws are sufficient to describe the observed static mechanic behaviour of soils. General ly, complex soil models tend to give better predictions than simple soil models. However, these complex soil models clearly require more involvement in terms of soil parameters, time and understanding of non - linear soil behaviour and techniques of numeri cal modelling. Thus, the selection of complex or simple analysis depends on what resources are avail able and how good a prediction is required.

d) Field monitoring is necessary to provide a means by which the geotechnical engineer can verify the design assumptions and the contractor can execute the work with safety and economy. More importantly, the field data may also be assembled into a compre hensive case record that is then available for use when checking the validity of any analytical and nu merical models. The ongoing process of back - anal ysis can help to refine and improve our understand ing, which in turn provides guidance for future designs. The available geological information at Lion Yard contributed significantly to the success of back - analysis and understanding of the performance of the basement at Lion Yard.

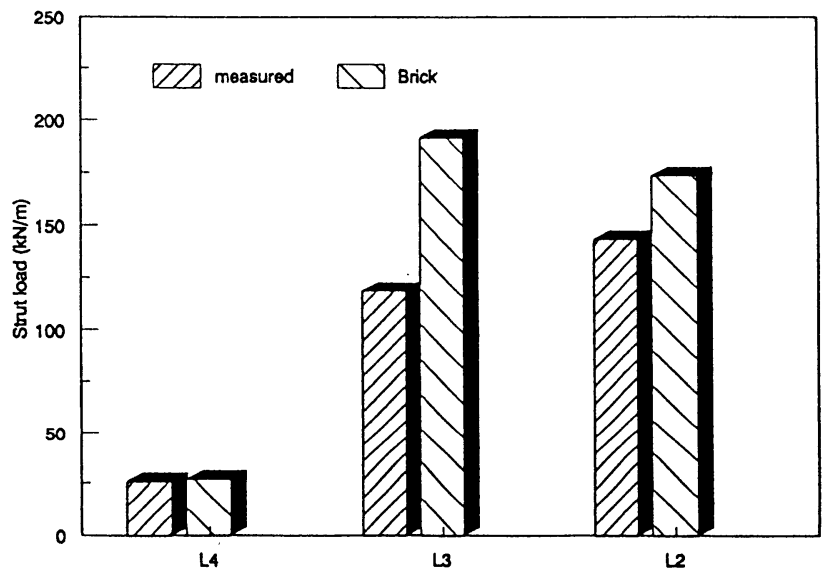

Fig.21 Comparison of the computed and measured propping forces

\section{REFERENCES}

Al - Tabbaa, A., and Wood, D. M. (1989) An experi mentally based bubble model for clay. Numerical methods in Geomechanics, NUMOG III, pp. 91 99, Elsevier Applied Science.

Atkinson, J. H. (1973) The deformation of undis turbed London Clay. Ph.D thesis, University of London, U. K.

Atkinson, J. H., Richardson, D., and Stallebrass, S. E. (1990) Effect of recent stress history on the stiffness of overconsolidated soil. Geotechnique, vol. 40, no. 4, pp. 531 - 540 .

Atkinson, J. H., and Sallfors, G. (1991) Experimen tal determination of stress - strain - time charac teristics in laboratory and in - situ tests. General report. Proc. 10th Eur. Conf. Soil Mech. and Fnd Engng, Florence, vol. 3, pp. 915 - 956.

Burland, J. B., Simpson, B., and St John, H. D. (1979) Movements around excavations in London Clay. Proc. 7th Eur. Conf. Soil Mech. and Fnd Engng, Brighton, vol. 1, pp. $13-19$.

Burland, J. B. (1990) On the compressibility and shear strength of natural clays. Geotechnique, vol. 40, no. 3, pp. 329 - 378.

Chatwin, C. P. (1961) British Regional Geology East Anglia and adjoining areas. 4th edition. Her Majesty's Stationary Office, London.

Georgiannou, V. N., Rampello, S., and Silvestri, F. (1991) Static and dynamic measurements of undrained stiffness on natural overconsolidated clays. Proc. 10th Eur. Conf. Soil Mech. \& Fnd Engng, Florence, vol. 1, pp. 91 - 95.

Goto, S., Tatsuoka, F., Shibuya, S., Kim, Y. S., and Sato, T. (1991) A simple gauge for local small strain measurements in the laboratory. Soils and Foundations, vol. 31, no.1, pp. $169-180$.

Jardine, R. J., Symes, M. J., and Burland, J. B. (1984) The measurement of soil stiffness in the triaxial apparatus. Geotechnique, vol. 34, no. 3, pp. $323-340$.

Jardine, R. J. (1985) Investigations of pile - soil be haviour with special reference to the foundations 
of offshore structures. Ph.D thesis, University of London, U. K.

Jardine, R. J. (1994) One perspective of the pre - fail ure deformation characteristics of some geoma terials. Proc. Int. Symp. on Pre-failure Defor mation Characteristics of Geomaterials, Hokkai do, Japan. Preprint volume, pp. 151 - 182.

Mair, R. J. (1993) Developments in geotechnical en gineering research: application to tunnels and deep excavations. Proc. Instn. Civ. Engrs. Civ. Engng., pp. 27 - 41.

Mroz, Z. (1967) On the description of anisotropic work hardening. J. Mech. Phys. Solids, vol. 15, pp. $163-175$.

Ng, C. W. W. (1992) An Evaluation of Soil -Structure Interaction Associated with a Multi - propped Ex cavation. Ph.D thesis, University of Bristol, U.K.

Ng, C. W. W., Bolton, M. D., and Dasari, G. R. (1995

a) The small strain stiffness of a carbonate stiff clay. Soils and Foundations. vol. 35, no.4, pp. 109 -114 .

Ng, C. W. W., Lings, M. L., Simpson, B., and Nash, D. F. T. (1995b) An approximate analysis of the three-dimensional effects of diaphragm wall in stallation. Geotechnique, vol. 45, no.3, pp. 497 507.

$\mathrm{Ng}, \mathrm{C} . \mathrm{W} . \mathrm{W}$., and Lings, M. L. (1995c) Effects of modelling soil non-linearity and wall installation on the back-analysis of a deep excavation in stiff clay. J. Geotech. Engng, Div., Am. Soc. Civ. Engrs., vol. 121, no. 10, pp. 687 - 695 .

Powell, J. J. M. (1990) A comparison of four differ ent pressuremeters and their methods of interpre tation in a stiffness heavily overconsolidated clay. Proc. 3rd Int. Symp. on Pressuremeter Testing, Oxford.

Schofield, A. N., and Wroth, C. P. (1968) Critical State Soil Mechanics. McGraw - Hill, London.

Schmidt, R. (1966) Discussions. Can. Geo. J., vol. 3, no.4, pp. 239 - 242.

Simpson, B., O'Riordan., N. J., and Croft, D. D. (1979) A computer model for the analysis of ground movements in London Clay. Geotechnique, vol. 29, no. 2, pp. $149-175$.

Simpson, B. (1992) Thirty - second Rankine Lecture: Retaining Structures: displacement and design. Geotechnique, vol. 42, no.4, pp. 541 - 576.

Tatsuoka, F., and Kohata, Y. (1994) Stiffness of hard soils and soft rocks in engineering applications. Proc. Int. Symp. on Pre-failure Deformation Characteristics of Geomaterials, Hokkaido, Japan. Preprint volume, pp. 227 - 336.

Terzaghi, K. (1925) Erdbaumechanik auf bodenphysikalischer Grundlage. Vienna: Deuticke, translated by A. Casagrande in From theory to practice in soil mechanics, New York, John Wiley and Sons, 1960.

Viggiani, G. (1992) Dynamic measurement of small strain stiffness of fine grained soils in the triaxial apparatus. Proc. Workshop on Experimental
Characterization and Modelling of Soils and Soft Rocks, Napoli, pp. 75 - 97.

Worssam, B. C., and Taylor, J. H. (1969) Geology of the country around Cambridge. 2nd edition. Her Majesty's Stationary Office, London. 